\title{
MANAGEMENT OF IRRIGATION AND FERTILIZATION FOR TWO WHEAT CULTIVARS UNDER SPRINKLER IRRIGATION SYSTEM IN NEW VALLEY GOVERNORATE
}

\author{
Khalil, E. S. ${ }^{(1)}$; Moubarak, M. Y. G. ${ }^{(2)}$ and Mejala, Nermeen, N. ${ }^{(2)}$ \\ 1) Institute of Environmental Studies \& Research, Ain Shams University. \\ 2) Agricultural Research Center.
}

\begin{abstract}
Two field experiments were carried out during two successive winter seasons of 2010/2011 and 2011/2012 in the experimental farm, Agricultural Research Station of El-Kharga, the New Valley Government under sprinkler irrigation system to study the effect of three irrigation regimes $(0.8,1.0$ and 1.2 IW:CPE), two wheat cultivars (Sakha-94 and Bani Suef-6) and four nitrogen fertilization treatments $\left(100 \%\right.$ inorganic-N, $\mathrm{F}_{1} ; 70 \%$ inorganic-N+3 ton compost $+\mathrm{N}$-fixers, $\mathrm{F}_{2} ; 70 \%$ inorganic-N +5 ton compost $+\mathrm{N}$-fixers, $\mathrm{F}_{3} ; 70 \%$ inorganic-N+7ton compost+ $\mathrm{N}$-fixers, $\mathrm{F}_{4}$ ) on yield and its components, actual evapotransiration and water use efficiency of wheat.

Results indicated that irrigated wheat plants with 1.2 IW: CPE increased biological, grain yields, $\mathrm{ET}_{\mathrm{a}}$ and WUE by $11.48,58.46,27.35$ and $24.27 \%$ as compared with $0.8 \mathrm{IW}: \mathrm{CPE}$, respectively.

The superiority of Bani Suef-6 wheat cultivar over Sakha-94 was confirmed for 1000-grain weight, biological, grain yields and WUE. Meanwhile, Sakha-94 cultivar gave the highest values of number of spikes per $\mathrm{m}^{2}$, straw yield and $\mathrm{ET}_{\mathrm{a}}$ compared to Bani Suef 6 cultivar.

Raising compost level from 0 to 7 ton fed $^{-1}$ with applying $\mathrm{N}$-fixers and decreasing inorganic $\mathrm{N}$ by $30 \%$ caused increasing 1000-grain weight, biological, grain yields, $\mathrm{ET}_{\mathrm{a}}$ and WUE.

In general, the followed interaction treatments were the best treatments because they gave highest grain yield and WUE: irrigated Bani Suef-6 plants with 1.2 IW:CPE+F 4 ; 1.2 IW:CPE+F 3 and 1.0 IW:CPE+F 4 .
\end{abstract}


Keywords: Irrigation, wheat cultivars, fertilization, yield and yield components

\section{INTRODUCTION}

Wheat is most important cereal food crop in Egypt. Its production doesn't meet the current demand so, Egyptian government dose more efforts to reduce the import percentage lower than $50 \%$ from the total consumption (Yassen et al., 2006). This strategy will achieved through expand cultivated area of wheat side by side with increasing productivity of unit area (Waley, 2008). It is well known that increasing wheat productivity of newly reclaimed lands could be attained by only selecting suitable wheat cultivars but also by improving agricultural practices such as irrigation management, integrated use of organic manures and biofertilizers with inorganic nitrogen fertilization. In this regard, Shang and Mao (2009) revealed that irrigation and fertilization have significant impact on wheat yield and water use efficiency (WUE) application of FYM (Sushila and Gajendra, 2000) or bio-fertilization with Microbein (Attia and Barsoum, 2013) increased the growth, yield and water use efficiency of wheat under limited of water supply.

Therefore, the aim of this study was investigated the effect of irrigation regimes and integrated inorganic $\mathrm{N}$ and compost as well as biofertilizers on yield and its components of two wheat cultivars under the New Valley conditions.

\section{MATERIALS AND METHODS}

The present study was carried out during the two successive winter growth seasons of 2010/2011 and 2011/2012 at the Research Farm, Agricultural Research Station, El-Kharga, New Valley Governorate, Egypt. 
The aim of this study was investigate the effect of irrigation, cultivars and partially substitution of inorganic $\mathrm{N}$ fertilizer with compost as well as biofertilizer on wheat productivity and water use efficiency under sprinkler irrigation system. The treatments were three irrigation regimes $(0.8,1.0$ and 1.2 IW:CPE), two wheat cultivars (Sakha-94 and Bani Suef-6) and four N fertilization treatments $\left(100 \%\right.$ inorganic-N, $\mathrm{F}_{1} ; 70 \%+3$ ton compost $+\mathrm{N}-$ fixers, $\mathrm{F}_{2} ; 70 \%+5$ ton compost $+\mathrm{N}$-fixers, $\mathrm{F}_{3} ; 70 \%+7$ ton compost $+\mathrm{N}$-fixers, $\mathrm{F}_{4}$ ). Nitrogen-fixers were Azospirillum Spp and Bacillus polymyxa.

The soil texture was sandy loam and had an average $\mathrm{pH}$ value of 7.68 , organic matter value of $0.14 ; 35.09,7.11$ and $240.89 \mathrm{ppm}$ available $\mathrm{N}, \mathrm{P}$ and $\mathrm{K}$, respectively (averaged over of the two seasons for $0-0.6 \mathrm{~cm}$ of soil depth). The experiment was laid out in split-split plot design with four replications. The main plots were assigned for irrigation regimes, meanwhile, sub plots were assigned for wheat cultivars and sub-sub plots were assigned for $\mathrm{N}$ fertilization treatments.

The used sprinkler irrigation system was a solid set system with spacing of $12 \times 12 \mathrm{~m}$ between laterals and between sprinklers. Sprinkler flow rate was 1.2-1.5 $\mathrm{m}^{3} \mathrm{~h}^{-1}$ at 2-3 bars. Monthly meteorological data collected from ElKharga Weather Station are show in Table (1). 
J. Environ. Sci.

Institute of Environmental Studies and Research - Ain Shams University

Table. 1. Meteorological data at El-Kharga during the two growing seasons

\begin{tabular}{|c|c|c|c|c|c|c|c|c|c|c|}
\hline \multirow{3}{*}{$\begin{array}{l}\bar{\Xi} \\
\bar{E}\end{array}$} & \multicolumn{6}{|c|}{ Temperature $\left({ }^{\circ} \mathbf{C}\right)$} & \multirow{2}{*}{\multicolumn{2}{|c|}{ RH\% }} & \multirow{2}{*}{\multicolumn{2}{|c|}{$\begin{array}{l}\text { Wind speed } \\
\qquad\left(\mathrm{m} \mathrm{s}^{-1}\right)\end{array}$}} \\
\hline & \multicolumn{2}{|c|}{ Max } & \multicolumn{2}{|c|}{ Min } & \multicolumn{2}{|c|}{ Mean } & & & & \\
\hline & $\mathbf{S}_{1}$ & $\mathbf{S}_{2}$ & $\mathbf{S}_{1}$ & $\mathbf{S}_{2}$ & $\overline{S_{1}}$ & $\mathbf{S}_{2}$ & $\mathbf{S}_{1}$ & $\mathbf{S}_{2}$ & $\mathbf{S}_{1}$ & $\mathbf{S}_{2}$ \\
\hline Nov & 32.1 & 26.1 & 17.1 & 11.6 & 24.5 & 19.0 & 38.7 & 43.7 & 3.06 & 4.20 \\
\hline Dec & 25.5 & 22.8 & 9.4 & 8.1 & 17.4 & 15.5 & 43.6 & 49.6 & 2.44 & 2.84 \\
\hline Jan & 22.6 & 20.3 & 7.2 & 4.9 & 14.7 & 12.8 & 50.2 & 49.7 & 2.12 & 2.08 \\
\hline Feb & 26.5 & 24.3 & 10.5 & 10.2 & 18.3 & 17.3 & 40.8 & 37.1 & 2.55 & 3.24 \\
\hline Mar & 28.2 & 26.6 & 12.6 & 11.2 & 20.7 & 19.4 & 31.8 & 33.2 & 3.22 & 3.40 \\
\hline
\end{tabular}

The experiment was sown after fallow during the two seasons. The compost was thoroughly incorporated into the surface $20 \mathrm{~cm}$ soil layer, 15 days before planting. The used compost properties and irrigation water are given in Table (2).

Table 2: Some properties of date palm compost and irrigation water

\begin{tabular}{|l|c|l|c|}
\hline Compost parameters & Values & Water properties & Values \\
\hline \hline PH $(1: 10$ suspension $)$ & 8.38 & $\mathrm{EC}\left(\mathrm{dS} \mathrm{m}^{-1}\right)$ & 0.51 \\
\hline $\mathrm{EC}(1: 10) \mathrm{dS} \mathrm{m}^{-1}$ & 3.45 & $\mathrm{pH}$ & 6.77 \\
\hline Weight of $^{3}(\mathrm{~kg})$ & 400 & $\mathrm{SAR}$ & 1.12 \\
\hline Total-N $(\%)$ & 0.90 & $\mathrm{Fe}(\mathrm{ppm})$ & 1.15 \\
\hline Total-P $(\%)$ & 0.79 & $\mathrm{Mn}(\mathrm{ppm})$ & 0.10 \\
\hline Total-K $(\%)$ & 0.94 & & \\
\hline Organic matter\% & 26.97 & & \\
\hline Organic carbon\% & 15.64 & & \\
\hline C/N ratio & 17.38 & & \\
\hline
\end{tabular}

Before sowing immediately wheat grain were inoculated with $\mathrm{N}$-fixers at a rate $0.5 \mathrm{~kg} \mathrm{fed}^{-1}$. Wheat grains were hand drilled at the rate of $60 \mathrm{~kg} \mathrm{fed}^{-1}$ on 24 and 26 November during the two seasons, respectively. The experimental plot area was $10 \mathrm{~m}^{2}(2 \times 5 \mathrm{~m})$ there were 10 rows in each plot spaced $0.2 \mathrm{~m}$ and 
$5 \mathrm{~m}$ long. Plots separated by 0.5 to $1 \mathrm{~m}$ alleys. Nitrogen, phosphorous and potassium fertilizers were added in the form of ammonium nitrate $(33.5 \% \mathrm{~N})$, supper phosphate $\left(15 \% \mathrm{P}_{2} \mathrm{O}_{5}\right)$ and potassium sulfate $\left(48 \% \mathrm{~K}_{2} \mathrm{O}\right)$. Phosphorous and potassium fertilizers were applied at rates $30 \mathrm{~kg} \mathrm{P}_{2} \mathrm{O}_{5} \mathrm{fed}^{-1}$ and $24 \mathrm{~kg}$ $\mathrm{K}_{2} \mathrm{O}$ fed $^{-1}$. All cultural practices were followed as recommended for wheat crop through the two growing seasons.

The irrigation treatments started at 20 days after sown date. All experimental units received equal amounts of water during germination. The amounts of irrigation water applied were measured by flow meter. The daily pan evaporation data was used for scheduling irrigation. Irrigation treatments were given once in three days interval. The pan was located near the experimental research station field. The following equation (Doorenbos and Pruitt, 1977) was used to calculate the potential evapotranspiration $\left(\mathrm{ET}_{\mathrm{p}}\right)$ :

$\mathrm{ET}_{\mathrm{p}}=\mathrm{E}_{\mathrm{pan}} \times \mathrm{K}_{\mathrm{pan}}$

where:

$\mathrm{E}_{\mathrm{pan}}=$ pan evaporation $\left(\mathrm{mm} \mathrm{day}^{-1}\right)$

$\mathrm{K}_{\mathrm{pan}}=$ pan coefficient $(0.7)$

At harvest, number of spikes $\mathrm{m}^{-2}, 1000$-grain weight, biological and grain as well as straw yields were measured.

\section{Actual crop evapotranspiration $\left(\mathbf{E T}_{\mathrm{a}}\right)$ :}

Actual crop evapotranspiration under different treatments was measured directly by measuring changes in soil water content using Time Domain Reflectometry (TDR), model Trase System1 6050 X I at depth 0 to $0.6 \mathrm{~m}$, according to Israelson and Hansen (1962) as follows: 


$$
E T a=\sum_{i=1}^{n=4}\left(\theta_{2}-\theta_{1}\right) \times d / 100
$$

Where: $\mathrm{ET}_{\mathrm{a}}=$ Actual crop evapotranspiration; $\mathrm{n}=$ number of layers; $\theta_{1}=$ soil moisture $\%$ before irrigation $\left(\mathrm{v} \mathrm{v}^{-1}\right) ; \theta_{2}=$ soil moisture $\% 24 \mathrm{~h}$ after irrigation $\left(\mathrm{v} \mathrm{v}^{-1}\right) ; \mathrm{d}=$ soil depth $(\mathrm{cm})$.

\section{Water use efficiency:}

$$
\text { WUE }\left(\mathrm{kg} \mathrm{m}^{-3}\right)=\frac{\text { grain yield }\left(\mathrm{kg} \mathrm{fed}^{-1}\right)}{\text { Consumptive water use }\left(\mathrm{m}^{3} \mathrm{fed}^{-1}\right)}
$$

\section{Statistical analysis:}

The results were statistically analyzed according to Gomez and Gomez (1984), using the computer MSTAT.C statistical analysis package by Freed et al. (1989). The least significant differences (L.S.D) probability level of $5 \%$ was manually calculated compare the differences among means.

\section{RESULTS AND DISCUSSION}

The combined analysis was used to discuss the effect of irrigation regimes, wheat cultivars and $\mathrm{N}$ fertilization treatments and their interactions.

\section{Yield and its components:}

The combined analysis of variance over two studied seasons for the main effect of irrigation regimes, wheat cultivars and $\mathrm{N}$ fertilization treatments is presented in Table (3).

Data showed that number of spikes per $\mathrm{m}^{2} ; 1000$-grain weight, biological, grain and straw yields were significantly affected by the irrigation regimes. The highest values of these characters except straw yield were obtained with 1.2 IW:CPE. In this context, biological and grain yields were 
increased by 11.48 and $58.46 \%$ as compared with 0.8 IW:CPE, respectively. On the other hand, the maximum value of straw yield was recorded when wheat plants irrigated by $0.8 \mathrm{IW}: \mathrm{CPE}$. It could be concluded that increasing irrigation water up to $1.2 \mathrm{IW}: \mathrm{CPE}$ ratios had led to an increase in the ability of wheat plants to produce more grain yield. In another study, El-Garawany et al. (1998) investigated the effect of three irrigation treatments (0.6, 1 and 1.4 IW:CPE ratios) under sprinkler irrigation system on wheat. They found that grain yield affected by irrigation treatments which agree with the results obtained in this study.

It is obvious from the data that, the two wheat cultivars yielded differently. The superiority of Bani Suef-6 wheat cultivar over Sakha-94 was confirmed for 1000-grain weight, biological and grain yields. Meanwhile, number of spikes per $\mathrm{m}^{2}$ and straw yield were higher for Sakha-94 cultivar than that Bani Suef-6 cultivar. The differences in the genetically make up and/or the interaction of genetic environmental condition might owe much to the varietal differences detected between cultivars herein (Byan et al., 2002).

Comparing between $\mathrm{N}$ fertilization treatments shows a different trend between treatments for all studied tails. Raising compost level from 0 to 7 ton fed $^{-1}$ with $\mathrm{N}$-fixers and decreasing inorganic $\mathrm{N}$ by $30 \%$ caused increasing all studied trials, except straw yield. Where, application of $\mathrm{F}_{4}$ treatment gave highest values of no. spikes per $\mathrm{m}^{2}$ as well as grain yield. While, the maximum value of biological yield were recoded by $\mathrm{F}_{3}$ treatment. Inorganic $\mathrm{N}$ treatment gave highest value of straw yield. Fertilization treatments had insignificant effect on 1000-grain weight. The enhancing effect of compost and nitrogen-fixers on grain yield might be due to the 
simulation effect between compost and nitrogen-fixers inoculation on improving the physical properties of the soil, increasing soil fertility and increasing the availability of many nutrients to plant uptake, which reflected on improving the grain yield (Shaaban, 2006; Metin et al., 2010; Ahmed et al., 2011).

Table. 3. Combined analysis for response of two wheat cultivars to irrigation regimes and $\mathrm{N}$ fertilization on yield and its components.

\begin{tabular}{|c|c|c|c|c|c|}
\hline Treatments & $\begin{array}{c}\text { No. } \\
\text { Spikes }_{2}^{-}\end{array}$ & $\begin{array}{c}\text { 1000- } \\
\text { grains } \\
\text { weight }(\mathrm{g})\end{array}$ & $\begin{array}{c}\text { Biological } \\
\text { yield } \\
\left(\text { kgfed }^{-1}\right)\end{array}$ & $\begin{array}{c}\text { Grain yield } \\
\left(\text { kgfed }^{-1}\right)\end{array}$ & $\begin{array}{c}\text { Straw yield } \\
{\left(\text { kgfed }^{-1}\right)}^{-1}\end{array}$ \\
\hline \multicolumn{6}{|c|}{ Irrigation regimes } \\
\hline $0.8 \mathrm{IW}: \mathrm{CPE}$ & 275.39 & 39.94 & 5840.63 & 1810.07 & 4030.56 \\
\hline 1.0 IW:CPE & 290.03 & 41.74 & 6120.31 & 2426.59 & 3693.72 \\
\hline 1.2 IW:CPE & 295.17 & 42.57 & 6510.94 & 2868.18 & 3642.76 \\
\hline LSD 0.05 & 3.57 & 1.96 & 106.65 & 78.48 & 83.82 \\
\hline \multicolumn{6}{|l|}{ Wheat cultivars } \\
\hline Sakha-94 & 290.55 & 40.25 & 6033.33 & 2095.43 & 3937.91 \\
\hline Bani Suef 6 & 283.18 & 42.58 & 6281.25 & 2641.13 & 3640.12 \\
\hline F test & $*$ & $*$ & $*$ & $*$ & $*$ \\
\hline \multicolumn{6}{|c|}{ N Fertilization treatments } \\
\hline F1 & 261.54 & 41.38 & 6047.92 & 2040.06 & 4007.86 \\
\hline $\mathrm{F} 2$ & 272.96 & 41.58 & 6016.67 & 2227.45 & 3789.22 \\
\hline F3 & 291.04 & 41.90 & 6385.42 & 2478.38 & 3907.03 \\
\hline F4 & 321.92 & 40.80 & 6179.17 & 2727.22 & 3451.95 \\
\hline LSD 0.05 & 4.76 & ns & 141.47 & 83.54 & 177.59 \\
\hline
\end{tabular}

Results recorded in Table (4) indicate that the interaction effect between irrigation regimes and wheat cultivars on mentioned trials was significant except biological yield. Sakha-94 plants received 1.2 IW: CPE gave the highest number of spikes per $\mathrm{m}^{2}$. While, the maximum values of 1000-grain weight, biological and grain yields were recoded by Bani Suef- 6 cultivar with the same 
irrigation treatment. Supplied Bani Suef-6 and Sakha-94 plants with 0.8 IW:CPE and 1.0 IW:CPE gave maximum values of straw yield.

Table. 4. Combined analysis for the effect of the interaction between irrigation regimes and wheat cultivars on yield and its components.

\begin{tabular}{|c|c|c|c|c|c|c|}
\hline $\begin{array}{c}\text { Irrigation } \\
\text { regimes }\end{array}$ & $\begin{array}{l}\text { Wheat } \\
\text { cultivars }\end{array}$ & $\begin{array}{c}\text { No. } \\
\text { Spikes } \\
\text { m }^{-2} \\
\end{array}$ & $\begin{array}{c}\text { 1000- } \\
\text { grains } \\
\text { weight }(\mathrm{g}) \\
\end{array}$ & $\begin{array}{c}\text { Biological } \\
\text { yield } \\
\left(\text { kgfed }^{-1}\right) \\
\end{array}$ & $\begin{array}{c}\text { Grain } \\
\text { yield } \\
\left(\text { kgfed }^{-1}\right) \\
\end{array}$ & $\begin{array}{c}\text { Straw } \\
\text { yield } \\
\left(\text { kgfed }^{-1}\right) \\
\end{array}$ \\
\hline \multirow{2}{*}{$\begin{array}{c}0.8 \\
\text { IW:CPE }\end{array}$} & Sakha94 & 267.22 & 37.43 & 5650.00 & 1735.62 & 3914.38 \\
\hline & Bani Suef6 & 283.56 & 42.46 & 6031.25 & 1884.52 & 4146.73 \\
\hline \multirow{2}{*}{$\begin{array}{c}1.0 \\
\mathrm{IW}: \mathrm{CPE}\end{array}$} & Sakha94 & 298.91 & 42.48 & 6021.88 & 1875.09 & 4146.78 \\
\hline & Bani Suef6 & 281.16 & 41.01 & 6218.75 & 2978.08 & 3240.67 \\
\hline \multirow{2}{*}{$\begin{array}{c}1.2 \\
\text { IW:CPE }\end{array}$} & Sakha94 & 305.53 & 40.85 & 6428.13 & 2675.57 & 3752.56 \\
\hline & Bani Suef6 & 284.81 & 44.28 & 6593.75 & 3060.79 & 3532.96 \\
\hline \multicolumn{2}{|c|}{ LSD 0.05} & 6.37 & 1.85 & $\mathrm{~ns}$ & 129.49 & 187.09 \\
\hline
\end{tabular}

The interaction effect between irrigation regimes and $\mathrm{N}$ fertilization treatments are presented in Table (5). Data indicated that irrigated plants with 1.2 IW:CPE and fertilized with $\mathrm{F}_{4}$ gave the highest values of number of spikes per $\mathrm{m}^{2}$ as well as grain yield, while $\mathrm{F}_{2}$ and $\mathrm{F}_{3}$ recoded the maximum values of 1000-grain weight and biological yield, respectively. On contrary, the highest straw yield was recoded with $0.8 \mathrm{IW}: \mathrm{CPE}+\mathrm{F}_{3}$. 
J. Environ. Sci.

Institute of Environmental Studies and Research - Ain Shams University

Table. 5. Combined analysis for the effect of the interaction between irrigation regimes and $\mathrm{N}$ fertilization treatments on yield and its components.

\begin{tabular}{|c|c|c|c|c|c|c|}
\hline $\begin{array}{l}\text { Irrigation } \\
\text { regimes }\end{array}$ & $\begin{array}{l}\mathbf{N} \\
\text { fert. }\end{array}$ & $\begin{array}{l}\text { No. Spikes } \\
\text { m }^{-2}\end{array}$ & $\begin{array}{c}1000- \\
\text { grains } \\
\text { weight }(\mathrm{g}) \\
\end{array}$ & $\begin{array}{c}\text { Biological } \\
\text { yield } \\
\left(\text { kgfed }^{-1}\right)\end{array}$ & $\begin{array}{c}\text { Grain yield } \\
\left(\text { kgfed }^{-1}\right)\end{array}$ & $\begin{array}{c}\text { Straw yield } \\
\left.\text { (kgfed }^{-1}\right)\end{array}$ \\
\hline \multirow{4}{*}{$\begin{array}{c}0.8 \\
\text { IW:CPE }\end{array}$} & $\mathrm{F}_{1}$ & 257.69 & 41.76 & 5462.50 & 1551.70 & 3910.80 \\
\hline & $\mathrm{F}_{2}$ & 260.13 & 37.90 & 5506.25 & 1668.51 & 3837.74 \\
\hline & $\mathrm{F}_{3}$ & 279.31 & 40.14 & 6581.25 & 1898.29 & 4682.96 \\
\hline & $\mathrm{F}_{4}$ & 304.44 & 39.97 & 5812.50 & 2121.78 & 3690.73 \\
\hline \multirow{4}{*}{$\begin{array}{c}1.0 \\
\text { IW:CPE }\end{array}$} & $F_{1}$ & 255.13 & 41.86 & 6125.00 & 2159.75 & 3965.25 \\
\hline & $\mathrm{F}_{2}$ & 278.56 & 42.58 & 6031.25 & 2362.39 & 3668.86 \\
\hline & $\mathrm{F}_{3}$ & 301.75 & 42.89 & 5975.00 & 2341.30 & 3633.70 \\
\hline & $\mathrm{F}_{4}$ & 324.69 & 39.64 & 6350.00 & 2842.91 & 3507.09 \\
\hline \multirow{4}{*}{$\begin{array}{c}1.2 \\
\text { IW:CPE }\end{array}$} & $F_{1}$ & 271.81 & 40.53 & 6556.25 & 2408.73 & 4147.53 \\
\hline & $\mathrm{F}_{2}$ & 280.19 & 44.27 & 6512.50 & 2651.45 & 3861.05 \\
\hline & $\mathrm{F}_{3}$ & 292.06 & 42.68 & 6600.00 & 3195.56 & 3404.44 \\
\hline & $\mathrm{F}_{4}$ & 336.63 & 42.79 & 6375.00 & 3216.98 & 3158.03 \\
\hline \multicolumn{2}{|c|}{ LSD 0.05} & 8.25 & 2.72 & 245.03 & 144.70 & 307.60 \\
\hline
\end{tabular}

As shown in the combined analysis (Table, 6), the interaction effects between wheat cultivars and $\mathrm{N}$ fertilization treatments on number of spikes per $\mathrm{m}^{2}, 1000$-grain weight, biological, grain and straw yields were significant. The data indicate that Bani Suef-6 cultivar superior in increasing no. spikes per $\mathrm{m}^{2}$, biological and grain yields compared to Sakha-94 cultivar when fertilized with $\mathrm{F}_{4}$ as well as the heaviest 1000-grain weight was recoded by the same cultivar plants that fertilized with $\mathrm{F}_{2}$. Whereas, the maximum value of straw yield was obtained by Sakha-94 cultivar plants when fertilized with $\mathrm{F}_{3}$. 
Table. 6. Combined analysis for the effect of the interaction between wheat cultivars and $\mathrm{N}$ fertilization treatments on yield and its components.

\begin{tabular}{|c|c|c|c|c|c|c|}
\hline $\begin{array}{l}\text { Wheat } \\
\text { cultivars }\end{array}$ & $\begin{array}{c}N \\
\text { fert. }\end{array}$ & $\begin{array}{c}\text { No. } \\
\text { Spikes } \\
\text { m }^{-2}\end{array}$ & $\begin{array}{c}\text { 1000- } \\
\text { grains } \\
\text { weight }(\mathrm{g})\end{array}$ & $\begin{array}{c}\text { Biological } \\
\text { yield } \\
\left(\mathrm{kgfed}^{-1}\right)\end{array}$ & $\begin{array}{c}\text { Grain yield } \\
\left(\text { kgfed }^{-1}\right)\end{array}$ & $\begin{array}{c}\text { Straw } \\
\text { yield } \\
\left.\text { (kgfed }^{-1}\right)\end{array}$ \\
\hline \multirow{4}{*}{ Sakha-94 } & $\mathrm{F}_{1}$ & 269.79 & 39.72 & 6020.83 & 1842.83 & 4178.01 \\
\hline & $\mathrm{F}_{2}$ & 278.04 & 39.38 & 6000.00 & 2044.99 & 3955.01 \\
\hline & $\mathrm{F}_{3}$ & 298.92 & 43.11 & 6437.50 & 2170.93 & 4266.57 \\
\hline & $\mathrm{F}_{4}$ & 315.46 & 38.80 & 5675.00 & 2322.96 & 3352.04 \\
\hline \multirow{4}{*}{$\begin{array}{l}\text { Bani Suef } \\
6\end{array}$} & $F_{1}$ & 253.29 & 43.05 & 6075.00 & 2237.29 & 3837.71 \\
\hline & $\mathrm{F}_{2}$ & 267.88 & 43.78 & 6033.33 & 2409.91 & 3623.43 \\
\hline & $\mathrm{F}_{3}$ & 283.17 & 40.70 & 6333.33 & 2785.83 & 3547.50 \\
\hline & $\mathrm{F}_{4}$ & 328.38 & 42.80 & 6683.33 & 3131.48 & 3551.85 \\
\hline \multicolumn{2}{|c|}{ LSD 0.05} & 6.73 & 2.22 & 200.07 & 118.14 & 251.15 \\
\hline
\end{tabular}

In the combined analysis, data in Table (7) indicate that the effect of interaction between irrigation regimes, wheat cultivars and $\mathrm{N}$ fertilization treatments on abovementioned properties was significant. Also, data reveal superiority of Bani Suef 6 cultivar than Sakha-94 for all studied trails, except straw yield. Where, irrigated Bani Suef 6 plants with 1.2 IW:CPE and fertilized with $\mathrm{F}_{4}$ gave the highest number of spikes per $\mathrm{m}^{2}$, biological and grain yields. As well as it recoded heaviest 1000- grain weight when irrigated with 1.2 IW:CPE and fertilized with $\mathrm{F}_{2}$. On the other hand, irrigated Sakha-94 cultivar with 0.8 IW:CPE and fertilized with $F_{3}$ gave highest straw yield. 
J. Environ. Sci.

Institute of Environmental Studies and Research - Ain Shams University

Table. 7. Combined analysis for the effect of the interaction between irrigation regimes, wheat cultivars and $\mathrm{N}$ fertilization treatments.

\begin{tabular}{|c|c|c|c|c|c|c|c|}
\hline $\begin{array}{l}\text { Irrigation } \\
\text { regimes }\end{array}$ & $\begin{array}{l}\text { Wheat } \\
\text { cultivars }\end{array}$ & $\begin{array}{l}\mathbf{N} \\
\text { fert. }\end{array}$ & $\begin{array}{l}\text { No. } \\
\text { Spikes } \\
\text { m }^{-2}\end{array}$ & $\begin{array}{c}1000- \\
\text { grains } \\
\text { weight } \\
(\mathrm{g})\end{array}$ & $\begin{array}{c}\text { Biological } \\
\text { yield } \\
\left(\text { kgfed }^{-1}\right)\end{array}$ & $\begin{array}{c}\text { Grain } \\
\text { yield } \\
\left.\text { (kgfed }^{-1}\right)\end{array}$ & $\begin{array}{c}\text { Straw } \\
\text { yield } \\
\left(\text { kgfed }^{-1}\right)\end{array}$ \\
\hline \multirow{8}{*}{$\begin{array}{c}0.8 \\
\text { IW:CPE }\end{array}$} & \multirow{4}{*}{$\begin{array}{l}\text { Sakha- } \\
94\end{array}$} & $\mathrm{~F}_{1}$ & 252.00 & 37.85 & 5475.00 & 1637.65 & 3837.35 \\
\hline & & $\mathrm{F}_{2}$ & 254.63 & 32.60 & 5337.50 & 1659.45 & 3678.05 \\
\hline & & $\mathrm{F}_{3}$ & 272.88 & 41.34 & 6737.50 & 1739.48 & 4998.03 \\
\hline & & $\mathrm{F}_{4}$ & 289.38 & 37.91 & 5050.00 & 1905.90 & 3144.10 \\
\hline & \multirow{4}{*}{$\begin{array}{l}\text { Bani } \\
\text { Suef } 6\end{array}$} & $\mathrm{~F}_{1}$ & 263.38 & 45.68 & 5450.00 & 1465.75 & 3984.25 \\
\hline & & $\mathrm{F}_{2}$ & 265.63 & 43.20 & 5675.00 & 1677.58 & 3997.43 \\
\hline & & $\mathrm{F}_{3}$ & 285.75 & 38.94 & 6425.00 & 2057.10 & 4367.90 \\
\hline & & $\mathrm{F}_{4}$ & 319.50 & 42.03 & 6575.00 & 2337.65 & 4237.35 \\
\hline \multirow{8}{*}{$\begin{array}{c}1.0 \\
\text { IW:CPE }\end{array}$} & \multirow{4}{*}{$\begin{array}{l}\text { Sakha- } \\
94\end{array}$} & $\mathrm{~F}_{1}$ & 270.50 & 43.36 & 6000.00 & 1536.95 & 4463.05 \\
\hline & & $\mathrm{F}_{2}$ & 280.13 & 44.13 & 6012.50 & 1730.43 & 4282.08 \\
\hline & & $\mathrm{F}_{3}$ & 316.50 & 44.35 & 5862.50 & 1971.60 & 3890.90 \\
\hline & & $\mathrm{F}_{4}$ & 328.50 & 38.08 & 6212.50 & 2261.40 & 3951.10 \\
\hline & \multirow{4}{*}{$\begin{array}{l}\text { Bani } \\
\text { Suef } 6\end{array}$} & $F_{1}$ & 239.75 & 40.35 & 6250.00 & 2782.55 & 3467.45 \\
\hline & & $\mathrm{F}_{2}$ & 277.00 & 41.03 & 6050.00 & 2994.35 & 3055.65 \\
\hline & & $\mathrm{F}_{3}$ & 287.00 & 41.44 & 6087.50 & 2711.00 & 3376.50 \\
\hline & & $\mathrm{F}_{4}$ & 320.88 & 41.21 & 6487.50 & 3424.43 & 3063.08 \\
\hline \multirow{8}{*}{$\begin{array}{c}1.2 \\
\text { IW:CPE }\end{array}$} & \multirow{4}{*}{$\begin{array}{l}\text { Sakha- } \\
94\end{array}$} & $\mathrm{~F}_{1}$ & 286.88 & 37.94 & 6587.50 & 2353.88 & 4233.63 \\
\hline & & $\mathrm{F}_{2}$ & 299.38 & 41.41 & 6650.00 & 2745.10 & 3904.90 \\
\hline & & $\mathrm{F}_{3}$ & 307.38 & 43.64 & 6712.50 & 2801.73 & 3910.78 \\
\hline & & $\mathrm{F}_{4}$ & 328.50 & 40.41 & 5762.50 & 2801.58 & 2960.93 \\
\hline & \multirow{4}{*}{$\begin{array}{l}\text { Bani } \\
\text { Suef } 6\end{array}$} & $\mathrm{~F}_{1}$ & 256.75 & 43.11 & 6525.00 & 2463.58 & 4061.43 \\
\hline & & $\mathrm{F}_{2}$ & 261.00 & 47.13 & 6375.00 & 2557.80 & 3817.20 \\
\hline & & $\mathrm{F}_{3}$ & 276.75 & 41.73 & 6487.50 & 3589.40 & 2898.10 \\
\hline & & $\mathrm{F}_{4}$ & 344.75 & 45.16 & 6987.50 & 3632.38 & 3355.13 \\
\hline \multicolumn{3}{|c|}{ LSD 0.05} & 11.66 & 3.85 & 346.53 & 204.63 & 435.01 \\
\hline
\end{tabular}




\section{Irrigation water-plant relationships}

Actual evapotranspiration $\left(\mathbf{E T}_{\mathbf{a}}\right)$ : Statistical analysis showed that main effects were significant in water consumptive use (WCU), while the interactions had insignificant effects (Table, 8).

It is obvious that $\mathrm{ET}_{\mathrm{a}}$ increased by increasing the amount of irrigation water from 0.8 IW:CPE to 1.2 IW:CPE. Actual $\mathrm{ET}_{\mathrm{a}}$ amounted to 1769.56, 1919.68 and $2253.59 \mathrm{~m}^{3} \mathrm{fed}^{-1}$ when wheat plants were supplied by 0.8 IW:CPE, 1.0 IW:CPE and 1.2 IW:CPE, respectively. This is quite expected as the abundance of soil moisture content resulted in low moisture stress in tissues of wheat plants and hence decreased stomata resistance leading to increase transpiration. These results are in agreement with those obtained by El-Garhi et al. (2003).

Data in Table (8) indicate that Sakha-94 cultivar consumed more water than Ban Suef-6 under different irrigation regimes. This is may be due to the differences in their genotype rather than environmental one.

The results indicated that $\mathrm{ET}_{\mathrm{a}}$ values were significantly affected by the compost levels applied in the fertilization treatments. Applying 3 to 7 ton compost per feddan increased $\mathrm{ET}_{\mathrm{a}}$ compared to inorganic $\mathrm{N}$ fertilization treatment. Meanwhile, increasing compost level from 3 to 7 ton $\mathrm{fed}^{-1}$ had insignificant effect on actual evapotranspiration. These results may be due to the effect of the applied organic matter on physical soil properties, and chemical characteristics of the soil, i.e. bulk density, water holding capacity, air porosity and $\mathrm{pH}$ and nutrient's availability. This may enhance the roots to absorb more water causing more transpiration and increasing the vegetative growth components, which resulted in more transpiration. These results are in 
a harmony with those found by Aziz (2002) and Ghosh et al (2003)

Table. 8. Combined analysis for the effect of irrigation regimes, wheat cultivars and $\mathrm{N}$ fertilization on $\mathrm{ET}_{\mathrm{a}}$

\begin{tabular}{|l|c|}
\hline \multicolumn{1}{|c|}{ Treatments } & ET $_{\mathbf{a}}\left(\mathbf{m 3 ~ f e d}^{-\mathbf{1}}\right)$ \\
\hline Irrigation regimes & 1769.56 \\
\hline 0.8 IW:CPE & 1919.68 \\
\hline 1.0 IW:CPE & 2253.59 \\
\hline 1.2 IW:CPE & 186.80 \\
\hline LSD 0.05 & 2026.5 \\
\hline Wheat cultivars & 1935.4 \\
\hline Sakha-94 & $*$ \\
\hline Bani Suef 6 & 1924.09 \\
\hline F test & 1984.76 \\
\hline N fertilization treatments & 2005.23 \\
\hline F1 & 2009.70 \\
\hline F2 & 32.96 \\
\hline F3 & \\
\hline F4 & \\
\hline LSD 0.05 & \\
\hline
\end{tabular}

Water use efficiency (WUE)

Regarding, the effect of irrigation regimes, data in Table (9) revealed that the differences between the averages of WUE were significant. Irrigating wheat plants at 1.2 IW:CPE gave the highest WUE value However, irrigation at $0.8 \mathrm{IW}$ :CPE gave the lowest WUE. It is clear that increasing irrigation amount from irrigation at 1.0 to $1.2 \mathrm{IW}$ :CPE insignificantly increased the WUE of wheat plants. It could be concluded that irrigating wheat plants at 1.0 or 1.2 IW:CPE significantly increased the efficiency of water use compared to $0.8 \mathrm{IW}$ :CPE. Such findings can be explained on the basis of although irrigation at 1.2 or $1.0 \mathrm{IW}: \mathrm{CPE}$ increased the actual evapotranspiration during 158 
the season, the increase in ETa gave pronounced increases in the grain yields, which surpassed the increase in ETa and this in turn increased the values of WUE. However, irrigation at $0.8 \mathrm{IW}$ :CPE subjected the plants to the water stress, which in turn produced the lowest grain yield with more reduction than the reduction in the actual evapotranspiration. The obtained results are in a harmony with those found by Farah et al. (1997) and Rayan and AbdelMawly (2001).

Data proved that WUE was significantly affected by wheat cultivars. Where, Ban Suef-6 cultivar demonstrated a better efficiency of water use than Sakha-94 under the New Valley conditions. This may be due to the reduction in the seasonal evapotranspiration of Ban Suef-6 cultivar and increasing grain yield as compared with Sakha-94.

The results in Table (9) proved that the WUE values were significantly affected by compost levels. Applying 7 ton compost per feddan gave the highest WUE value followed by 5 ton. It is evident that increasing compost level application to wheat caused significant increases in WUE values under these conditions. These results may be due to the effect of organic matter on improving physical and chemical soil characters and consequently increased the growth components and grain yield much more than the increase in the crop evapotranspiration. Whereas, planting without compost gave the lowest evapotranspiration and the lowest grain yield, but the reduction in grain yield was more than the reduction in the seasonal evapotranspiration of the crop. These results are fallen in the same line of those stated by Aziz (2002) and Ghosh et al (2003). 
Obtained results in Table (9) indicate that WUE were significantly affected by the interaction between irrigation regimes and wheat cultivars. Ban Suef-6 cultivar recoded the highest value of WUE when supplied with 1.0 IW:CPE.

Table (9) clarifies the results of WUE values by wheat and their close relation with the interaction between irrigation regimes and $\mathrm{N}$ fertilization treatments. Irrigated wheat plants with 1.0 IW:CPE and fertilized with $\mathrm{F}_{4}$ gave the highest WUE. The lowest WUE value was resulted from plants that supplied with $0.8 \mathrm{IW}: \mathrm{CPE}$ and fertilized with $\mathrm{F}_{1}$. It could be revealed that for high water use efficiency by wheat plants, compost and $\mathrm{N}$-fixers should be applied and irrigation must be practiced in medium irrigation regime (1.0 IW:CPE) especially in the sandy loam soils.

The interaction effects between wheat cultivars and $\mathrm{N}$ fertilization treatments on WUE were significant (Table, 9). The data indicate that Bani Suef-6 cultivar superior in increasing WUE compared to Sakha-94 cultivar with all fertilization treatments. The highest value of WUE recoded when Bani Suef-6 supplied with $F_{4}$, followed by $F_{3}$ and so on.

It is clear from Table (9) that the triple interaction between irrigation regimes, wheat cultivars and fertilization treatments had significant effect on WUE. In this regard, Ban Suef-6 plants supplied with1.0 IW:CPE $\mathrm{F}_{4}$ recoded highest value of WUE. 
Table. 9. Effect of irrigation regimes and $\mathrm{N}$ fertilization on water use efficiency of two wheat cultivars.

\begin{tabular}{|c|c|c|c|c|c|c|}
\hline $\begin{array}{c}\text { Irrigation } \\
\text { intervals (I) }\end{array}$ & $\mathrm{N}$ fert. $(\mathrm{N})$ & $\mathbf{F}_{1}$ & $\mathbf{F}_{2}$ & $\mathbf{F}_{3}$ & $\mathbf{F}_{4}$ & Mean \\
\hline \multirow{2}{*}{$0.8 \mathrm{IW}: \mathrm{CPE}$} & Sakha-94 & 0.93 & 0.92 & 0.95 & 1.05 & 0.96 \\
\hline & Ban Suef-6 & 0.87 & 0.97 & 1.18 & 1.34 & 1.09 \\
\hline \multicolumn{2}{|l|}{ Mean } & 0.90 & 0.94 & 1.07 & 1.19 & 1.03 \\
\hline \multirow{2}{*}{ 1.0 IW:CPE } & Sakha-94 & 0.82 & 0.89 & 0.99 & 1.14 & 0.96 \\
\hline & Ban Suef-6 & 1.54 & 1.59 & 1.43 & 1.81 & 1.59 \\
\hline \multicolumn{2}{|l|}{ Mean } & 1.18 & 1.24 & 1.21 & 1.47 & 1.27 \\
\hline \multirow{2}{*}{ 1.2 IW:CPE } & Sakha-94 & 1.06 & 1.19 & 1.21 & 1.20 & 1.17 \\
\hline & Ban Suef-6 & 1.16 & 1.18 & 1.62 & 1.63 & 1.39 \\
\hline \multicolumn{2}{|l|}{ Mean } & 1.11 & 1.18 & 1.41 & 1.41 & 1.28 \\
\hline \multicolumn{2}{|c|}{ N Fertilization means } & 1.06 & 1.12 & 1.23 & 1.36 & \\
\hline \multirow{2}{*}{$\begin{array}{l}\text { Cultivars x N } \\
\text { fertilization }\end{array}$} & Sakha-94 & 0.93 & 1.00 & 1.05 & 1.13 & 1.03 \\
\hline & Ban Suef-6 & 1.19 & 1.25 & 1.41 & 1.59 & 1.36 \\
\hline \multicolumn{2}{|c|}{ L.S.D 0.05 for irrigation (I) } & \multicolumn{5}{|c|}{0.12} \\
\hline \multicolumn{2}{|c|}{ L.S.D 0.05 for cultivars (C) } & \multicolumn{5}{|c|}{$*$} \\
\hline \multicolumn{2}{|c|}{ L.S.D 0.05 for I x C } & \multicolumn{5}{|c|}{0.12} \\
\hline \multicolumn{2}{|c|}{ L.S.D 0.05 for $\mathrm{N}$ fertilization } & \multicolumn{5}{|c|}{0.05} \\
\hline \multicolumn{2}{|c|}{ L.S.D 0.05 for I $x \mathrm{~N}$} & \multicolumn{5}{|c|}{0.08} \\
\hline \multicolumn{2}{|c|}{ L.S.D 0.05 for $\mathrm{C} \times \mathrm{N}$} & \multicolumn{5}{|c|}{0.07} \\
\hline \multicolumn{2}{|c|}{ L.S.D 0.05 for I $\times$ C x N } & \multicolumn{5}{|c|}{0.11} \\
\hline
\end{tabular}

\section{REFERENCES}

Ahmed, M. A.; Ahmed, A. G.; Mohamed, M. H. \& Tawfik, M. M. (2011). Integrated effect of organic and biofertilizers on wheat productivity in new reclaimed sandy soil. Research J. Agric. and Biolo. Sci., 7(1), 105-114.

Attia, M. A. \& Barsoum, M. S.; Mohamed, M. H. \& Tawfik, M. M. (2013). Effect of supplementary irrigation and bio-fertilization on wheat yield productivity under rainfed conditions. Alex. J. Agric. Res., 58 (2), 149-157. 
Aziz, N. G. M. (2002). Soil and water management of newly reclaimed soils. $\mathrm{Ph}$. D. Thesis, Faculty of Agriculture, Fayoum, Cairo University, Egypt.

Byan, U. A.; El-Shinawy, M. Z.; Gomaa, H. M. \& Mahmoud, M. H. (2002). Yield and water relation of cowpea and plants as affected by water regime. Arab Univ. J. Agric. Sci., Ain Shams Univ., Cairo, 10 (3), 847-865.

Doorenbos, J. \& Pruitt, W. O. 1977. Crop water requirements. Irrigation and drainage paper, No.24, FAO, Rome.

El-Garawany, M. M.; Said, M. A. \& Yehya, G. (1998). Effect of fertigation and applied water amounts on nitrogen and potassium fertilizer and water use efficiencies of wheat crop at newly reclaimed in Nubaria, Egypt. J. Agric Sci. Mansoura Univ., 23 (9), 41014112.

El-Garhi, I. A.; M. K. Matter; S. A. Abdel hafiz \& Sidrak, N. N. (2003). Evapotrnspiration rates from wheat as affected by scheduling irrigation, timing and rates of nitrogen fertilizer. Zagazig J. Agric. Res., 30 (3), 819 - 832.

Farah, S. M.; Saleh, A. A.; Taha, A. M., Ali, Z. I. \& Ali, I. A. (1997). Grain sorghum response to supplementary irrigations under post-rainy season conditions. Agricultural Water Management, 33: 31-41.

Freed, R.P., Eisensmith, S.P.; Goelz, S.; Reicozky, D.; Smail, W.W.\& Woberg, P. (1989). MSTAT. A Softwar Program for Design, Management and Analysis of Agronomic Research Experiments. Dep. Crop and Soil Sci, Michigan Stat University, USA.

Ghosh, P. K.; Banyopadhyay, K. K.; Tripathi, A. M.; Hati, K. M.; Mandal, K. G. \& Misra, A. K. (2003). Effect of integrated management of farmyard manure, phosphocompost, poultry manure and inorganic fertilizers for rainfed sorghum (Sorghum bicolor) in vertisols of central India. Indian Journal of Agronomy, 48: 4852. 
Gomez, K. A. \& Gomez, A. A. (1984). Statistical Procedures For Agriculture Research. A Willy-Inter Science publication, John Wily and Sons, Inc. NewYork, USA.

Israelson, O. W. \& Hansen, V. E. (1962). Flow of water into and through soils. Irrigation principles and practices. $3^{\text {rd }}$ Edition, John Wiley and Sons, Inc., New York, N. Y., U.S.A.

Metin, T. A.; Medine, G. B.; Ramazan, C. C.; Taskin, O. F. \& Sahin D. (2010). The effect of PGPR strain on wheat yield and quality parameters. Proceeding of World Congress of Soil Science, Soil Solutions for a Changing World.1 - 6 August 2010, Brisbane, Australia.

Rayan, A. A. \& Abdel - Mawly, S. E. (2001). Scheduling the irrigation for grain sorghum under different levels of nitrogen fertilization in upper Egypt. Journal Agricultural Research, 28: 1159-1176.

Shaaban, S. M. (2006) Effect of organic and inorganic nitrogen fertilizer on wheat plant under water regime. J. Applied Sci. Res., 2 (10), 650-656.

Shang, S. and Mao, X. (2009). In IFIP International Federation for Information Processing, Volume 293, Computer and Computing Technologies in Agriculture II, Volume 1, eds. D. Li, Z. Chunjiang, (Boston: Springer), pp. 39-48.

Sushila, R. \& Gajendra, I. R. I. (2000). Influence of farmyard manure, nitrogen and biofertilizers on growth, yield components and yields of wheat under limited water supply .Indian J. Agron., 45, 590- 595.

Waly, A. A. E. (2008). Effect of some agronomic practices on growth and yield of some wheat cultivars under newly reclaimed soil. Ph. D. Thesis, Fac. Agric., Zagazig Univ., Egypt.

Yassen, A. A.; Abd El-Hady, M.; \& Zaghloul, S. M. (2006). Replacement part of mineral $\mathrm{N}$ fertilizer by organic ones and its effect on wheat plant under water regime conditions. World J. Agric. Sci., 2 (4), 421-428. 


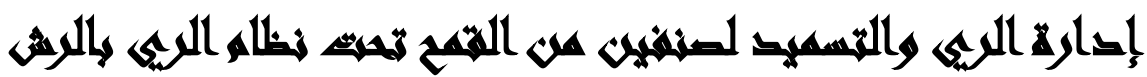

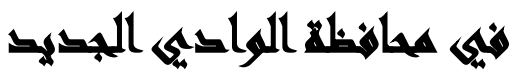

$[\wedge]$

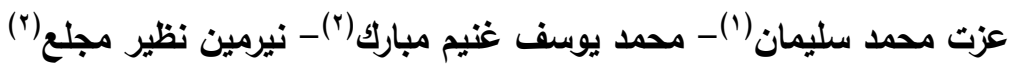

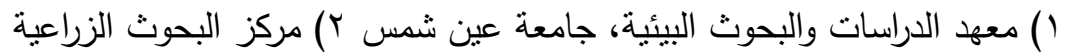

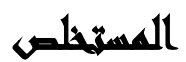

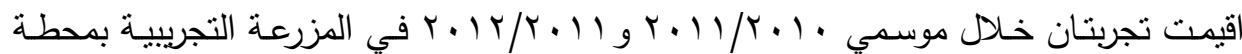

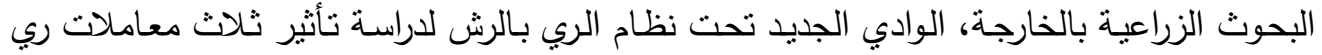

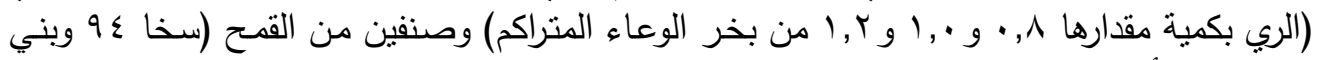

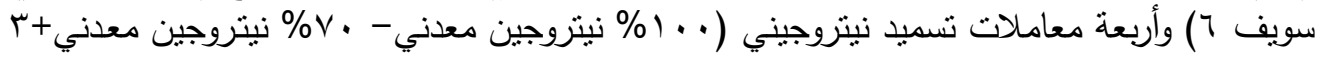

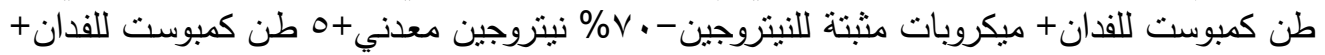

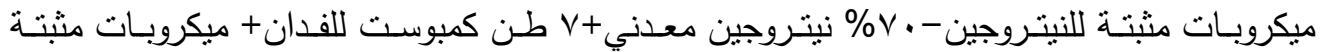

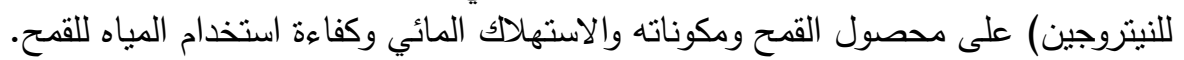
أوضحت النتائج الآتي:

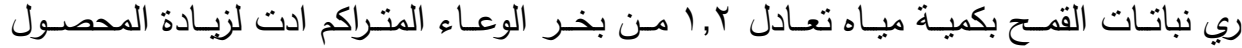

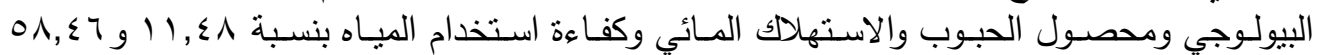

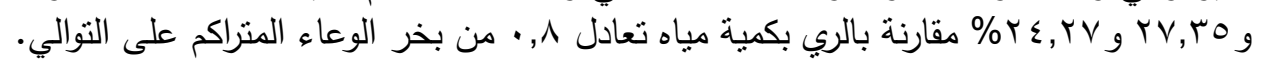

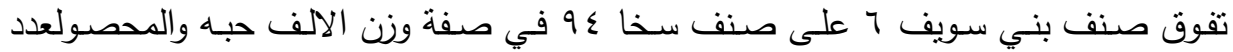
للسنابل في المتر المربع وأعلى محصول قش واستهلالك مائي مقارنة بالصنف بني سويف 7.

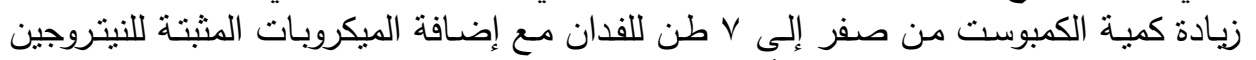

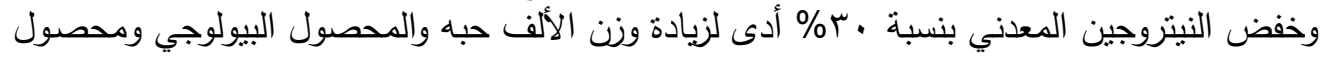
الحبوب والاستهلاك المائي وكفاءة استخدام المياه للقمدح.

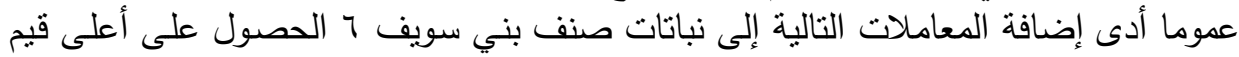

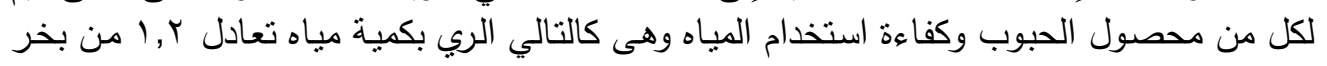

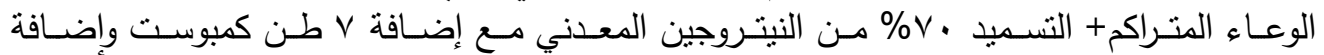

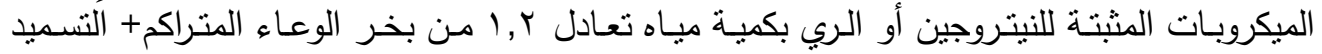

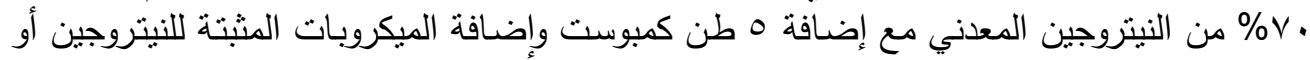

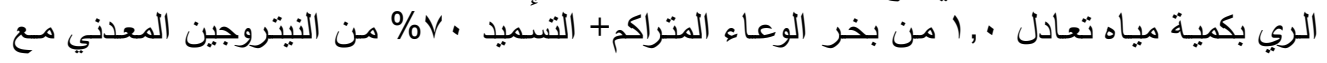
إضافة V طن كمبوست وإضافة الميكروبات المثبتة للنيتروجين 